\title{
Article \\ Marketing and Self-Promotion in Early Modern Painting: The Case of Guercino
}

\author{
Daniel M. Unger
}

\section{check for}

updates

Citation: Unger, Daniel M. 2021. Marketing and Self-Promotion in Early Modern Painting: The Case of Guercino. Arts 10: 55. https:// doi.org/10.3390/arts10030055

Academic Editor: Thor J. Mednick

Received: 18 July 2021

Accepted: 13 August 2021

Published: 18 August 2021

Publisher's Note: MDPI stays neutral with regard to jurisdictional claims in published maps and institutional affiliations.

Copyright: (C) 2021 by the author. Licensee MDPI, Basel, Switzerland. This article is an open access article distributed under the terms and conditions of the Creative Commons Attribution (CC BY) license (https:/ / creativecommons.org/licenses/by/ $4.0 /)$.
The Department of the Arts, Faculty of Humanities and Social Sciences, Ben-Gurion University of the Negev, Beer-Sheva 8410501, Israel; dannu@bgu.ac.il

\begin{abstract}
This article focuses on Guercino's Return of the Prodigal Son, commissioned in the name of Cardinal Alessandro Ludovisi and on his marketing choices. This is a case study in terms of selfpromotion tactics employed by an ambitious artist. My argument is that one finds in the painting a secondary and more sophisticated level of interpretation, which relates to the relationship between the painter and his patron. To the most traditional iconography of the scene, Guercino added musicians and spectators, thus positioning the entire composition in the theatre. One of the musicians is depicted in a way that casts him as a representative of the painter. The patron understood Guercino's intentions and commissioned what became Guercino's most important artworks. It was Guercino's ability of shifting the attention of a given iconography and deliver current political meaning that is discernible in his Roman works commissioned by the same Cardinal Ludovisi who was elected Pope Gregory XV.
\end{abstract}

Keywords: Guercino; Gregory XV; prodigal son; early modern theatre; self-presentation

\section{Introduction}

Today we may confidently assert the extent to which Guercino's career was impacted by Pope Gregory XV (Alessandro Ludovisi 1554-1623). In 1621, immediately after his elevation to the papal throne, ${ }^{1}$ the newly elected Ludovisi pope summoned the painter to Rome and commissioned him to depict The Burial and Reception into Heaven of St. Petronilla (1621/3, Pinacoteca Capitolina, Rome) for St. Peter's. ${ }^{2}$ Guercino was the first Bolognese painter to be called to the eternal city by this pope, where he created his most important works, and where he first encountered success and great acclaim.

The Burial and Reception into Heaven of St. Petronilla is Guercino's most prestigious work in Rome. In fact, this is the only major work of art commissioned by Pope Gregory XV for St. Peter's. This monumental altarpiece, which seems to have marked the climax of the painter's success, was installed above the altar that replaced the demolished chapel of the French kings, in which the remains of St. Petronilla had been interred by Pope Paul V in 1606 (Pinelli 2000, p. 646).

There are many questions concerning the reasons that motivated the Ludovisi pope to invite the obscure young painter from Cento to Rome. Foremost among these questions is: what exactly did the old clergyman find so compelling in Guercino's work? The answer to this question, as I would like to argue, can be found in one of the paintings that were commissioned on his behalf while he was still serving as the archbishop of Bologna, the Return of the Prodigal Son (Figure 1). ${ }^{3}$ It is unknown who commissioned the painting on behalf of the archbishop. It is very likely that Guercino's first encounter with the Ludovisi patronage was initiated by Alessandro's nephew Ludovico. ${ }^{4}$ The latter was an art connoisseur, and later created a major collection, housed at the Casino Ludovisi. ${ }^{5}$ 


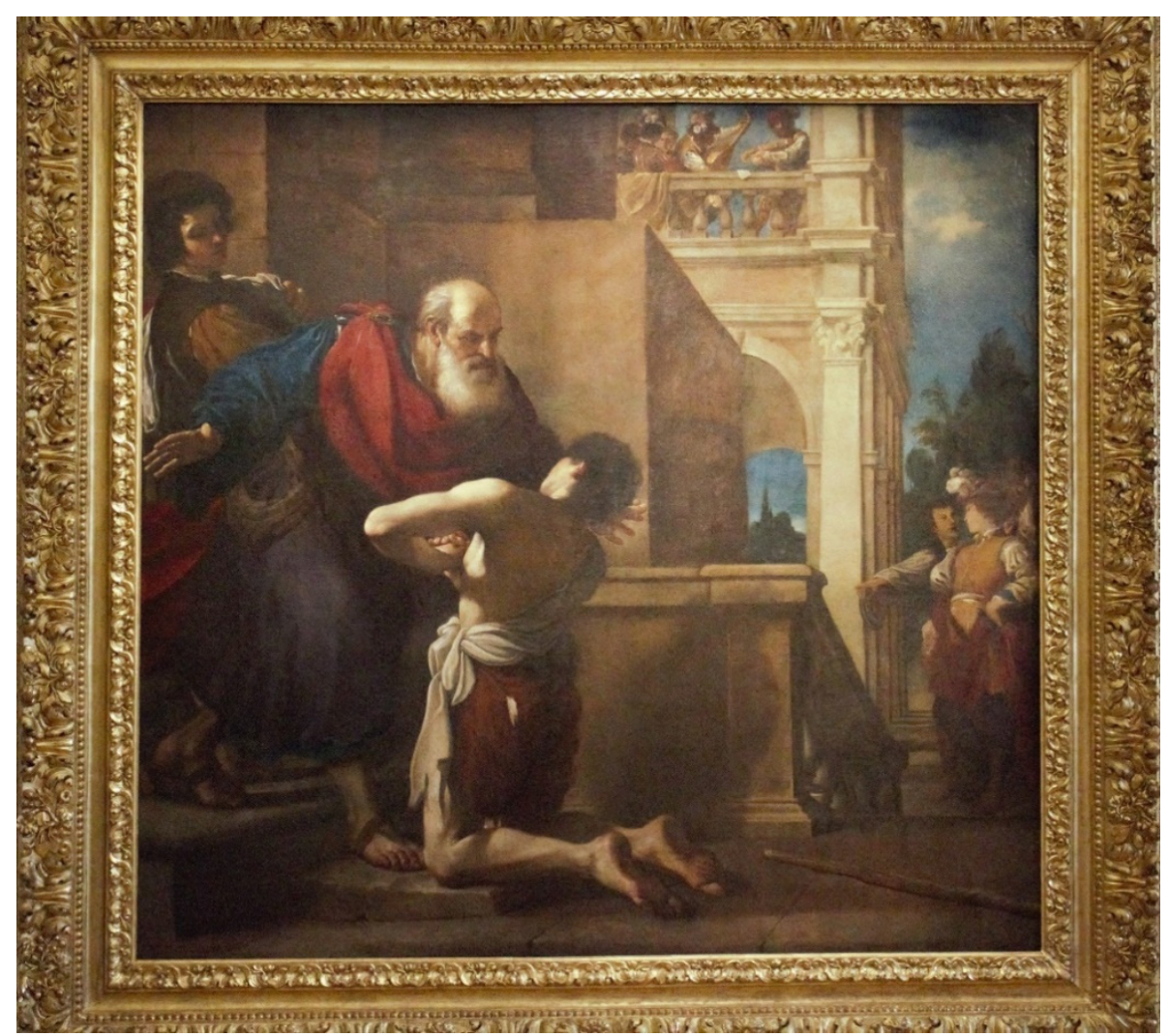

Figure 1. Guercino, Return of the Prodigal Son, 1618, Galleria Sabauda, Turin. Photo: (c) Daniel M. Unger.

In this essay I will argue that Cardinal Alessandro Ludovisi was fascinated by Guercino's ability to infuse familiar themes with additional layers of meaning, through the incorporation of particular elements that shift the viewer's attention from a well-known and common understanding of a given subject towards a more specific message. This ability, discerned in Guercino's St. Petronilla altarpiece, is also evident in the Return of the Prodigal Son. Indeed, the St. Petronilla altarpiece is a tour de force of Guercino's innovative employment of signs to direct the viewer towards the message, which goes beyond that which can be gleaned from the title of the painting (Unger 2010, pp. 10-11). Modern scholars, such as Leo Steinberg, Louise Rice, and Carolyn H. Wood, have already suggested political interpretations for this presentation, that is first and foremost a religious artwork meant to commemorate a Catholic saint (Steinberg 1980; Wood 1988; Rice 1997; Unger 2010).

A careful analysis of the Return of the Prodigal Son offers a similar intention that may explain Guercino's stunning early success and why he was the Pope's preferred painter. The painting should be explained in terms of an ambitious young painter seeking to make a name for himself. Indeed, for a painter at the outset of his career, it would seem natural to try and impress his viewers, and to search among them for a powerful patron by producing the most compelling painting possible-through actions which, in today's terminology, we could describe as marketing choices towards the creation of an effective commodity. In this regard, one should be constantly reminded that he was at the outset of his career when Guercino completed his first version of Return of the Prodigal Son. The painting was intended for a high-ranking patron, who paved his way toward fame and success. Thus, in this early commission, Guercino added a personal undercurrent note that was meant to impress the recipient of the painting-Alessandro Ludovisi. 


\section{The Ludovisi Commission}

The Return of the Prodigal Son is one of three paintings that Carlo Cesare Malvasia, the Bolognese biographer, mentions as having been completed by Guercino for Cardinal Ludovisi in 1618. The other two paintings are Raising of Tabitha and Susanna and the Elders (Prado, Madrid). According to Malvasia, these three works truly exceeded the cardinal's expectations. ${ }^{6}$ Susanna and the Elders is the only painting among the three that is mentioned in both Ludovisi inventories-those of 1623 and 1633. ${ }^{7}$ Nicholas Turner explains the absence of the Return of the Prodigal Son from both inventories, whereby the painting was given to the Duke of Savoy, Carlo Emanuele I by the Pope's nephew, Ludovico Ludovisi, soon after its execution. The painting is mentioned in the collection of the Duke, in the 1631 inventory. ${ }^{8}$

The actual return of the prodigal son is depicted on the left side of the painting in a highly traditional manner, and features the most climactic moment of the New Testament story (Luke 15, pp. 11-32), in which the prominently displayed son asks for his father's forgiveness. Guercino employed the familiar iconography associated with this scene, depicting the father descending the stairs while stretching out his arms in welcome. The son kneels in front of him, his hands clasped together, in a gesture commonly interpreted as remorse. Both father and son express their feelings by means of their hands. Behind the father is a third man, carrying a pile of clothes.

To the most conspicuous part of the painting —-the son's return - the painter added two groups of figures that may shift our understanding of the scene towards a more nuanced explanation of the painting. The first group, in the upper part of the composition, consists of five figures: three men who seem to be engaged in conversation, and two men with musical instruments, one tuning a theorbo and another holding a lira da braccio (Figure 2). ${ }^{9}$ Hornik and Parsons identified this group as musicians invited to play at the feast the father is preparing in honour of his returning son. Interestingly, both scholars acknowledge the inclusion of two distinct scenes in one painting: the reunion of the prodigal son and his father, and the feast for which the musicians were invited (Hornik and Parsons 2005, p. 147).

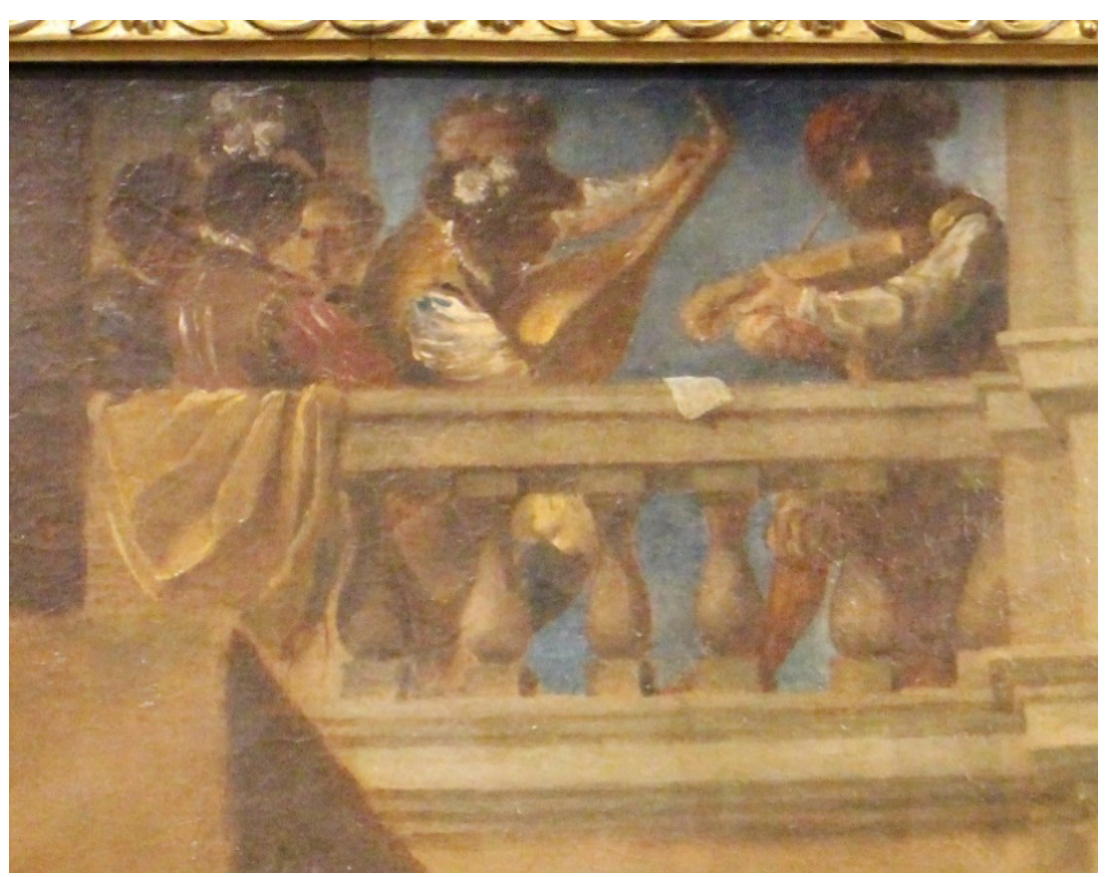

Figure 2. Guercino, Return of the Prodigal Son (detail), 1618, Galleria Sabauda, Turin. Photo: (C) Daniel M. Unger. 
The second group, on the far right, consists of two figures: a young man dressed in fancy seventeenth-century attire and a feathered hat, and a man in simple clothes standing behind him, who is showing him the way towards the staircase. He seems to belong to a lower social rank. A horse is positioned behind the men, indicating that the well-dressed gentleman has just arrived. The gentleman can certainly represent the loyal son returning from his daily work in the fields. Thus, here too, one may find a representation of two different instances of the same story: the reunion of the prodigal son and his father, and the return of the loyal son from the fields.

In his Suzanna and the Elders Guercino depicted the scene in the most traditional manner. The two elderly men are glancing on the naked Suzanna while she is seated, washing her feet. Yet, the painter succeeded in creating a dramatic and tempestuous scene, expressed in the movement, hand gestures, and facial expressions of the two men, featuring the most climatic moment of the story.

Guercino's Raising of Tabitha (Figure 3) is a more sophisticated painting. Here, in addition to the two main protagonists, St. Peter and Tabitha, he peopled his canvas with other figures. In this painting, the miracle of restoration of life is depicted, as St. Peter resurrects someone (Tabitha) who has recently passed away. Tabitha, a pious woman who lived in Jaffa and occupied herself with charitable works, died suddenly. St. Peter, who was in Lydda, was called in. He saw her lying dead and asked everyone to leave the room, and then called out, "Tabitha, surge", whereupon she opened her eyes and sat up (Acts 9, pp. 36-43).

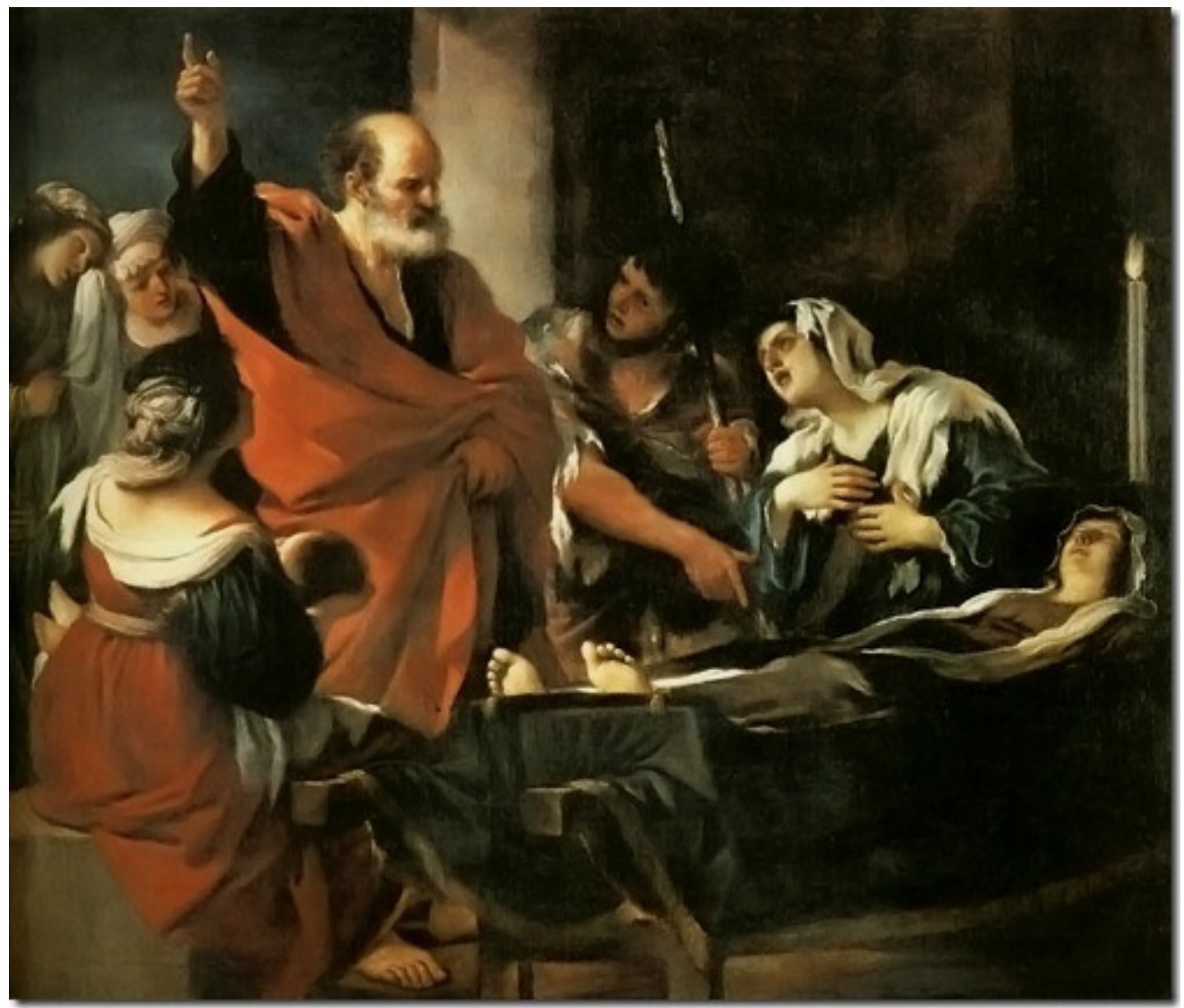

Figure 3. Guercino, Raising of Tabitha, 1618, Palazzo Pitti, Florence. Photo: Wikimedia Commons, Public Domain.

Guercino chooses the climactic moment as St. Peter cries out to the dead woman, who is depicted foreshortened lying in the lower right side of the picture, still lifeless. St. Peter, positioned on the left of the canvas, flings up his arm and points upward while looking 
at Tabitha and exhorting her to rise. Around the two main protagonists Guercino added a young shepherd between St. Peter and Tabitha, who is holding a staff in his left hand and, with his right, hand points down at the dead body, in a movement contrasting with St. Peter's upwardly pointing hand. He turns his head toward St. Peter. To the shepherd's left stands a woman, also looking at St. Peter with her hands on her breast. On the other side of St. Peter, there are three figures. One, in the frontal plane, sits with her back to the viewer, holding a baby and watching. Two other women are behind St. Peter. One holds a handkerchief close to her eyes and the other looks on from beyond St. Peter's shoulder. The scene is taking place in a dark room lightened by a single candlelight. According to Carolyn Kinder Carr, the women in The Raising of Tabitha are the widows who asked St. Peter to come to their help. Although St. Peter asked that the room be cleared, the iconographic tradition of this subject always included additional figures (Carr 1978, p. 128).

Whereas, Guercino's Return of the Prodigal Son follows the traditional iconography in terms of the representation of the three main protagonists and their interrelationship, the two additional groups of figures may have other meaning. They may be seen as musicians and spectators, thus positioning the entire composition in the theatre. Indeed, the entire composition alludes to the theatrical performance of a liturgical play (sacre rappresentazione), in which musicians and spectators supplement the three actors in the role of the father and his two sons.

The theatrical character of the entire composition is clarified when we compare the painting's background with Guercino's only surviving drawing of a full theatrical décor (Figure 4).

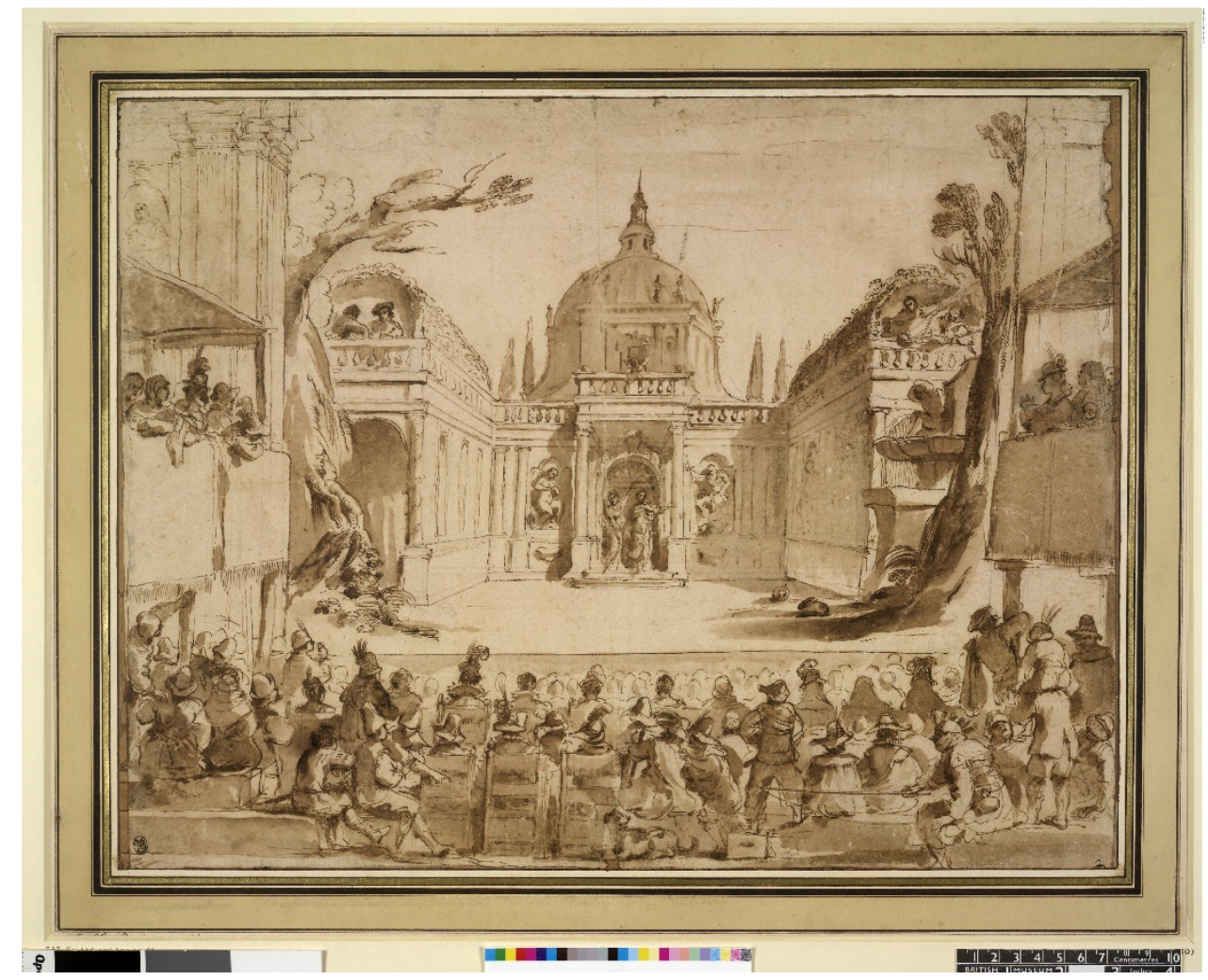

Figure 4. Guercino, A Theatrical Performance (drawing), 1617, The British Museum, London. Photo: (C) The Trustees of the British Museum.

In this drawing, two women are performing on stage, probably singing and dancing in front of a large crowd, which is seen from behind. On the right side of the drawing, on the second floor, on what seems to be a covered balcony, are two musicians with instruments, similar to those in the Return of the Prodigal Son..$^{10}$ In fact, the two musicians 
in the drawing of the theatre are located in the same spot in the theatre as those depicted in the painting. There is one fundamental difference, however, between the two pairs of musicians. Whereas the figures in the drawing are producing music, the most remarkable aspect of the two musicians in the painting is that they are not playing music (Figure 2). The theorbo player is intent on tuning his instrument, while the other musician is holding his instrument in a manner that makes it impossible for him to produce sounds, with the fingers of his left hand visible on the back of the lira da braccio.

From the musicians' perspective, it seems as if the three main protagonists of the New Testament parable are positioned on stage, while the diagonal view captures not only the actors and musicians on stage, but also the arrival, on the right, of the distinguished spectator who is being shown to his place.

\section{Guercino and the Theatre}

Guercino's involvement with the theatre of his day is well documented, and was thoroughly investigated by Shilpa Prasad in her doctoral dissertation, which focused on the centrality of theatrical dispositions in Guercino's work and on their development throughout his career (Prasad 2007). Bartolommeo Fabri, who built his theatre in Cento, Guercino's birthplace, employed the painter and made two rooms available to him for his academia del nudo in 1616 (Malvasia 1678, vol. 2, p. 258; Bagni 1984, p. 23; Salerno 1988, p. 8; Unger 2010, p. 55). Giuseppe Maria Pannini records Guercino's association with Fabri and the theatre in his 1655 Compendiosi ragguagli d'alcune attiioni seguite nella Nobilissima Patria di Cento (Prasad 2007, pp. 37-41; Prasad 2006, pp. 7-8). Malvasia mentions the Marquis Enzo Bentivoglio, a well-known figure in the theatrical world of his time, who came to visit Guercino at his home in Cento (Malvasia 1678, vol 2, p. 258; Prasad 2007, pp. 56-58). Letters written in 1617 by Guercino and by the Bolognese clergyman Don Antonio Mirandola, Guercino's lifelong mentor and friend, confirm a request that was made by Bentivoglio for a painting, and which was rejected by the painter because he was too busy. ${ }^{11}$

Prasad noticed another reference to Guercino's representations of theatrical performances in his Peasants in a Domestic Interior, where the painter duplicated the right side of another drawing, the Tavern Scene (Figure 5).

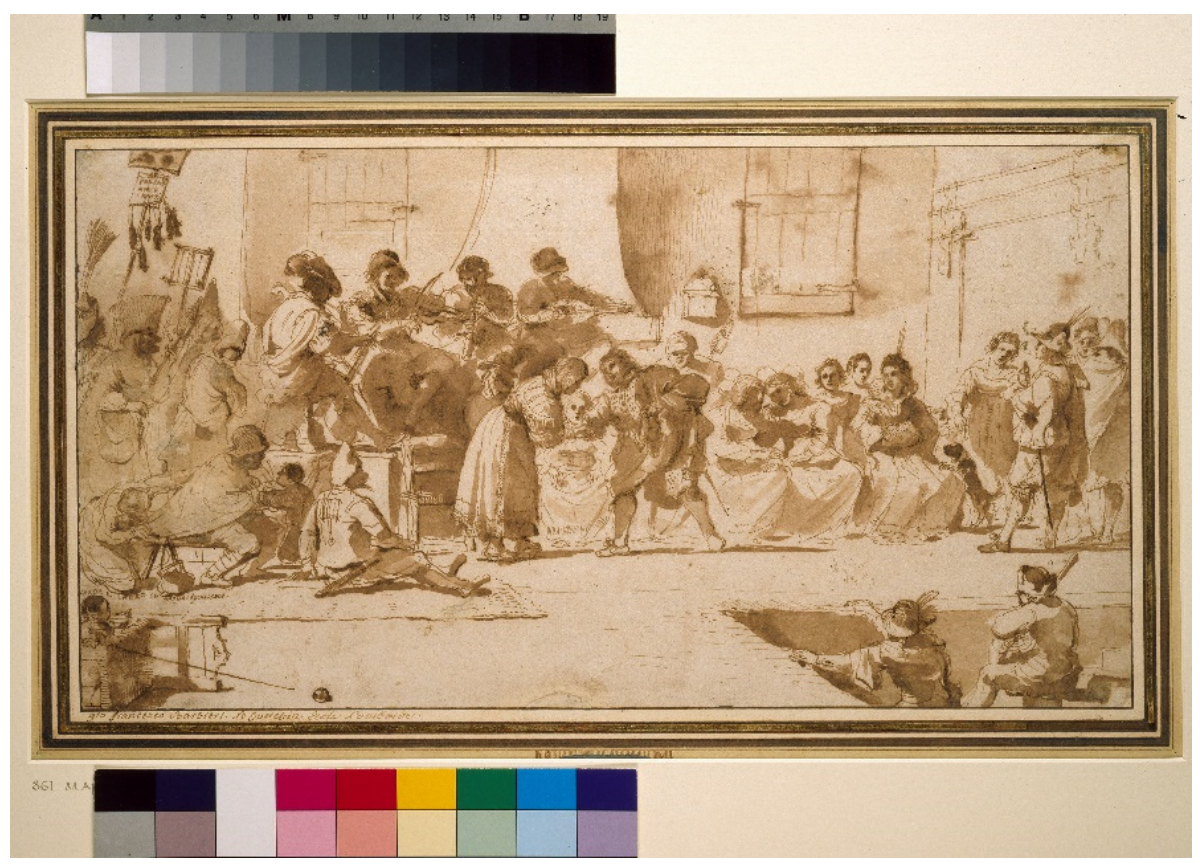

Figure 5. Guercino. Tavern Scene (drawing), the Ashmolean Museum, Oxford. Photo: (C) Ashmolean Image Library. 
While there is nothing in the domestic interior that relates to the theatre, the tavern scene represents a theatrical performance. In this work, the painter blurs the boundaries between theatre and life by depicting a stage with actors, musicians, and spectators, all intermingled so that the viewer cannot distinguish between them. ${ }^{12}$ Below the stage, two seated figures are depicted observing the stage. They, too, do not appear as regular audience members, and wear costumes that might connect them to the group of actors rather than to the group of spectators.

In this drawing, Guercino is blurring the boundaries between the two worlds. In contrast to the Return of the Prodigal Son, however, in this composition the figures behave as would be expected during a performance: the musicians play their instruments, the actors stand at centre stage, and the spectators observe them.

It is possible that it was Guercino's engagement with Fabri's theatre that influenced his decision to depict his first version of the Return of the Prodigal Son as if on a stage. Adding the two musicians on the upper right side could imply that the depicted scene was not the actual return of the Prodigal Son, but rather the theatrical performance of a liturgical play on this subject. The depicted theatrical performance represents two contrasting moments: while the musicians and the spectators are represented as if the show has not yet begunthe musicians are not producing music and the distinguished guest is not yet seated-the father and his two sons are rendered as if the show has already reached its climatic moment, in which the son kneels down as he pleads his father for forgiveness.

Whereas early seventeenth-century religious painting was meant to offer its viewers a representation of a coherent reality (Huddleston 2001, p. 19), Guercino's painting contrasts the action unfolding on stage with the behaviour of the musicians and spectators. As the dramatic scene reaches its climax, the musicians and the audience are caught unprepared. What makes Guercino's Return of the Prodigal Son so intriguing is precisely this absence of Aristotelian unity of plot or action, familiarized by Lodovico Castelvetro's translation of the Greek philosopher's Poetics into the vernacular in $1570 .{ }^{13}$ Castelvetro himself added two unities, the unity of place and the unity of time. ${ }^{14}$ Guercino's painting, however, contradicts the allusion to reality. This dissonance between the secondary figures and the main group deserves further attention, and may have served to direct the viewer, and more specifically, Cardinal Ludovisi, to the underlying message. Why, then, did Guercino choose to shift his emphasis from the return of the prodigal son to a theatrical performance of the scene? And, having chosen to depict such a scene, why did he insist on such a lack of Aristotelian unity, consistency, and decorum-all qualities that were viewed as fundamental for an early modern theatrical performance? It is as if Guercino, by subverting Aristotelian unity, was trying to shift the viewer's attention from the actual act of contrition toward the secondary figures. We may regard the three actors in full theatrical motion as rehearsing the scene. In that case, they parallel the position of the painter, who has not yet completed his work, and who has yet to reach the height of his career and realize his highest potential. Yet this explanation is rather limited, and does not addresses what seems to be a much more sophisticated marketing goal, centred on self-promotion, in light of a commission intended for a high-ranking patron.

Theatre and painting have been regarded as sister arts since the time of Aristotle, for both were forms of mimetic expression. In his La Carta del Navegar Pitoresco, Marco Boschini described painting in terms of a theatrical act: "Painting is like a comedy in which the spectator sits on his chair and observes a recital". ${ }^{15}$ The two additional groups emphasize the unique idea that this painting was meant to express, beyond its scriptural source. ${ }^{16}$ By adding groups of figures that belong to the theatre, the painter highlights his artistic abilities, creativity, and commitment, investing a familiar theme with a complex message intended for the most important viewer-Cardinal Alessandro Ludovisi.

\section{Guercino's Other Versions of the Return of the Prodigal Son}

Guercino's reasons for producing such a conceit remain a mystery, and a comparison between this painting and the other versions of this scene that Guercino created during his 
lifetime emphasizes the uniqueness of this choice. Guercino produced at least six additional versions of this scene after completing the painting for Ludovisi. The following year, he created a second version for Cardinal Serra (Figure 6). Denis Mahon attributed to Guercino a third version, based on stylistic grounds. This painting, writes Mahon, was completed in 1627/8 (Figure 7). ${ }^{17}$

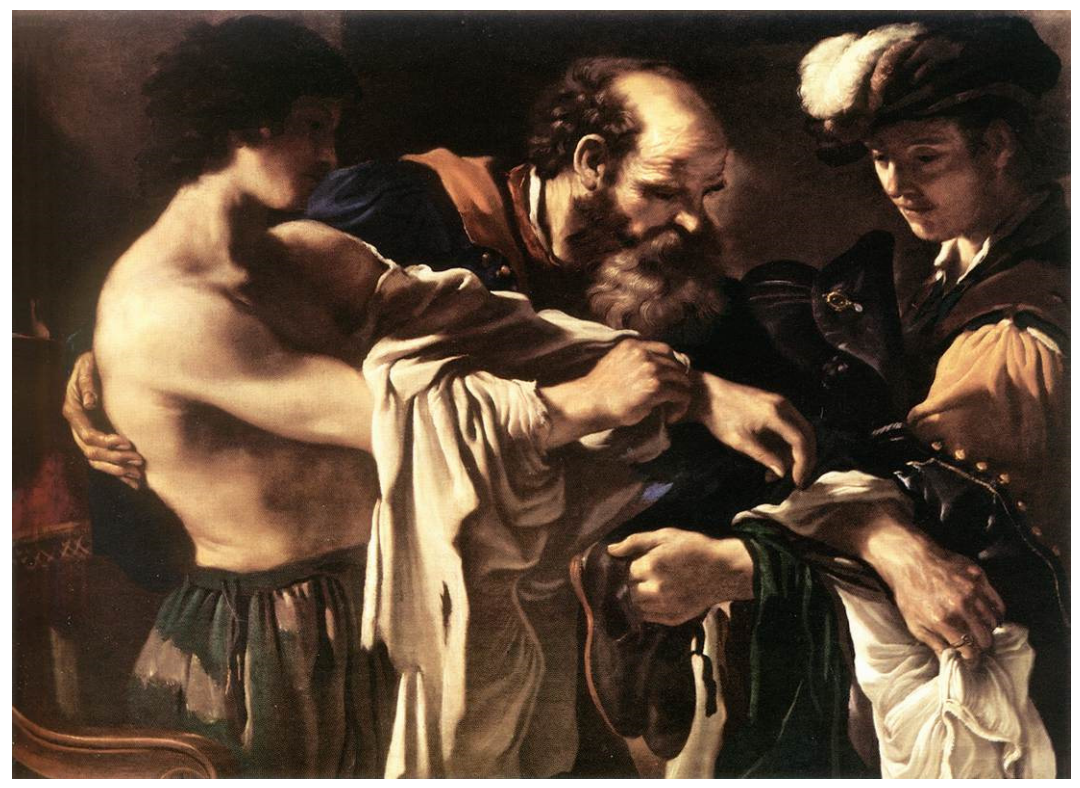

Figure 6. Guercino, Return of the Prodigal Son, 1619, Kunsthistorisches Museum, Vienna. Photo: Wikiart, Public Domain.

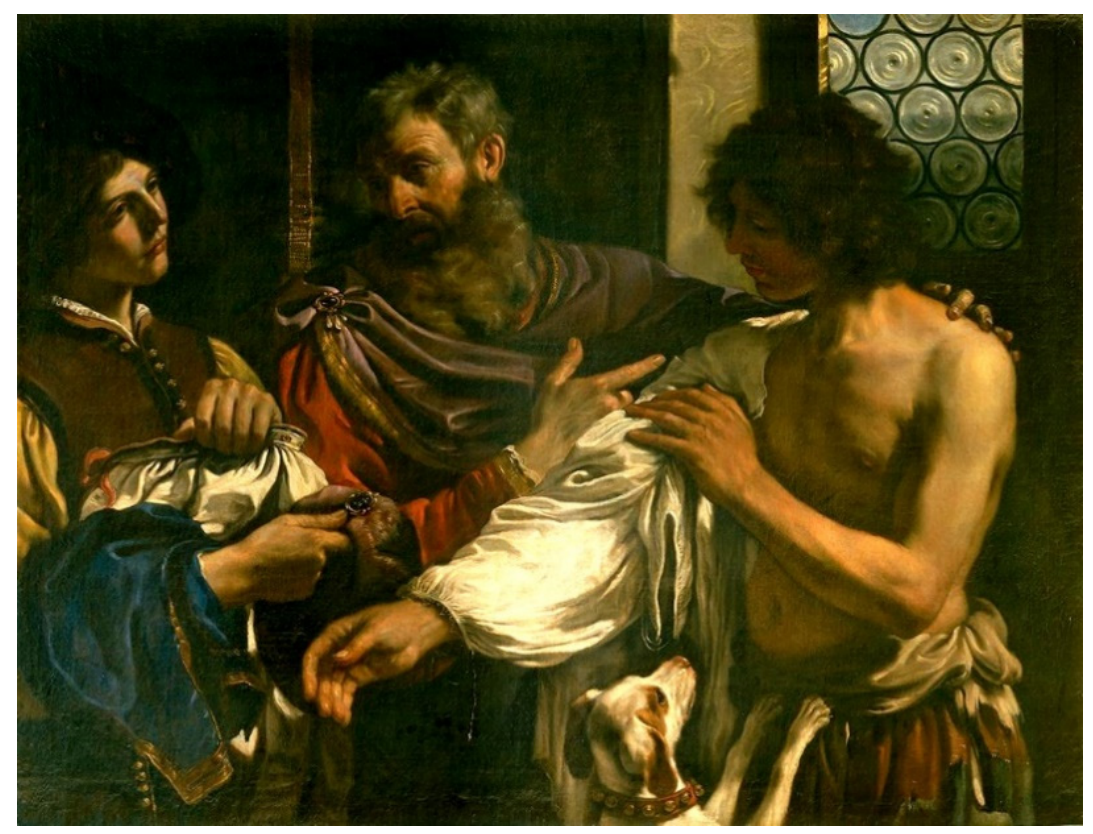

Figure 7. Guercino, Return of the Prodigal Son, 1627/8, Borghese Gallery, Rome. Photo: Wikimedia Commons, Public Domain.

Two other known representations are those made for the Venetian Giovanni Nanni in 1651 (Figure 8) and for the archbishop of Milan, Girolamo Boncompagni, in 1654/5 (Figure 9). This latter version was intended as a gift for Prince Colonna (Ghelfi 1997, pp. 151, 188; Hornik and Parsons 2005, pp. 151-53). Two other paintings that are considered lost are mentioned in the painter's accounts book. One of them is registered as having been 
commissioned in 1642 by Taddeo Barberini, a nephew of Pope Urban VIII (Malvasia 1678, vol. 2, p. 265; Ghelfi 1997, pp. 113-14; Vivian 1971, p. 23).

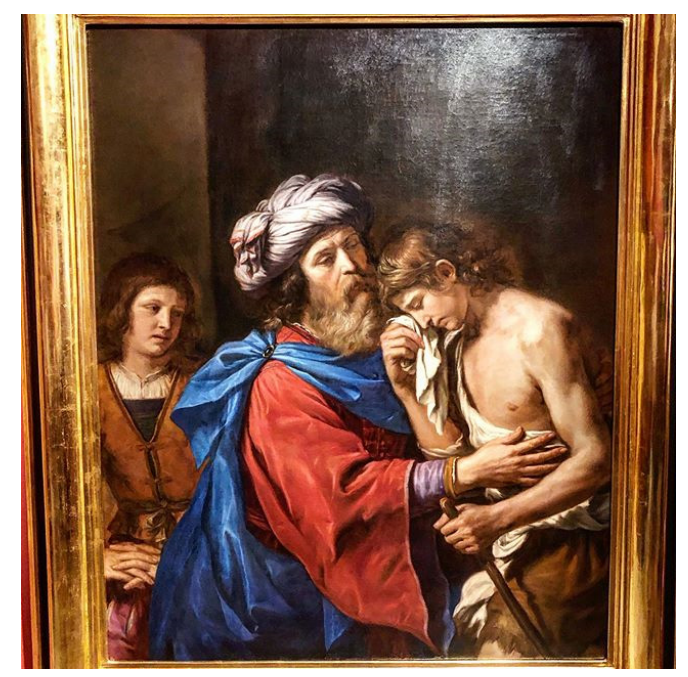

Figure 8. Guercino, Return of the Prodigal Son, 1651, Diocesan Museum, Wloclawek. Photo: Wikimedia Commons, Public Domain.

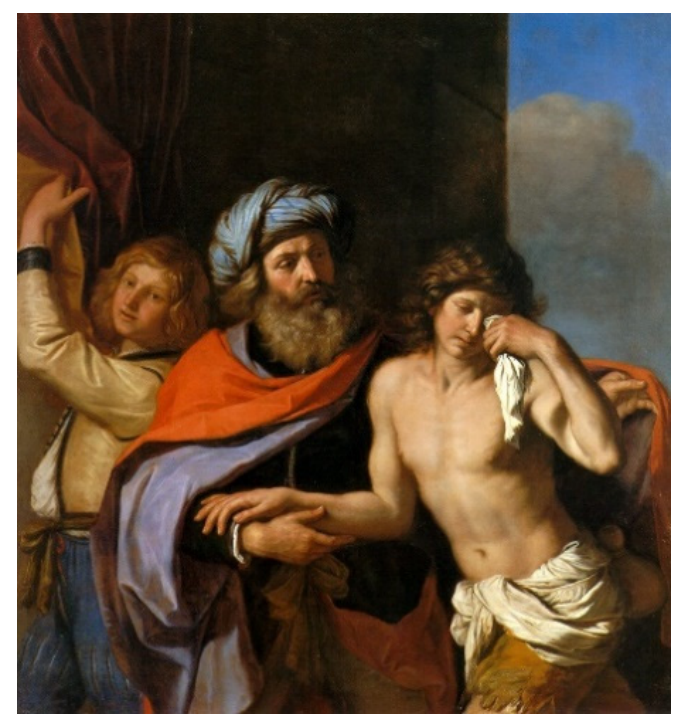

Figure 9. Guercino, Return of the Prodigal Son, 1654/5, Timken Museum, San Diego, CA, USA. Photo: Wikimedia Commons, Public Domain.

It is clear that among the five versions known to us today, the version intended for Cardinal Ludovisi is the only one that added additional groups to the parable's dense narrative. While its composition contains three groups of figures-actors, musicians and viewers-what characterizes the other paintings is a focused scene with only the three main protagonists depicted. The Sabauda painting is also the only version that corresponds to the traditional representation of the scene, with the prodigal son kneeling while clasping his hands together, his father descending the stairs with his wide-open arms, and a third protagonist carrying clothes. In all of Guercino's other renditions of the scene, the three main protagonists are responding to one another in other ways, without stressing the hierarchy between the embracing father and the kneeling son. Indeed, in these later representations, the prodigal is neither kneeling nor clasping his hands together in a typical gesture of contrition. Among the four later versions, the two earlier ones (Figures 6 and 7) relate to a different instance in the story - the changing of clothes. The two later versions 
(Figures 8 and 9) actually emphasize contrition, but in an almost theatrical manner, with the help of a handkerchief that the prodigal son is holding to his eyes. In the Timken version, this theatrical act of contrition is further emphasized by the turning of the prodigal son towards the viewer, away from his father.

\section{The Role of the Violinist}

Returning now to the group with the musicians (Figure 2), one cannot but notice that the violinist, in addition to holding a musical instrument, is directing his gaze toward the viewer, so that one may initially interpret this figure's role as to be that of an admonisher. This role is emphasized by the violinist's hands, which are grasping the lira da braccio and the bow unconventionally, thus, they seem like the hands of a painter holding a palette and brush. This way of holding the musical instrument and gazing at the viewer differs from the many renditions of violinists that Guercino painted during his long career. ${ }^{18}$ In some cases, the violinist is accompanied by a lute-player. In most instances, the violinist is no other than an angel, playing the violin while hovering over a saint. This can be seen, for example, in Guercino's St. Francis in Ecstasy (Warsaw, National Museum 1620), which is one example out of four paintings that the painter produced. The angel in these works is holding a violin in the proper manner, with the fingers of his left hand resting on the strings while he holds a bow in his right hand. St. Francis is reacting to the music with hand gestures. ${ }^{19}$ In his Landscape with a Concert (Figure 10, the violinist once again holds the musical instrument in the proper manner. This is also true of the angel on the left in Madonna and Child with Sts. Joseph, Agostino, Louis and Francis, the Donator and Two Angels (Brussels, Musées Royaux des Beaux Arts 1616), and Madonna and Child with St. Joseph and an Angel (Cleveland $\mathrm{OH}$, The Cleveland Museum of Art 1624). These depictions all differ significantly from the peculiar rendition of the musician holding the lira da braccio in Guercino's Return of the Prodigal Son. Whereas the musician usually opens his arms so that the viewer can see the violin's strings, in this painting the instrument is shown from the back, and the musician's outstretched arm blocks our view of the strings. Moreover, the bow seems to be pointed towards the viewer, rather than in the opposite direction. In this depiction, the musician gazes attentively at the viewer, while pointing his bow towards him. This attentiveness may be seen in such examples as Botticelli's self-portrait in his Adoration of the Magi (Uffizi, Florence 1475) (Lightbown 1978, vol. 2, pp. 45-46; Paolucci 2003, pp. 69-76), Ghirlandaio's self-portrait in the Resurrection of the Notary's Son (Sassetti Chapel, Santa Trinita, Florence, 1483/6) (Forsook and Offerhaus 1981, p. 41), and Raphael's self-portrait in his School of Athens (Stanza della Segnatura, Apostolic Palace, Vatican) (Unger 2012, pp. 269-87). The difference between Guercino's musician and the depictions of these three masters mentioned here is that Guercino did not incorporate his own image into the composition. Guercino's depiction of the musician thus requires attention not in terms of self-portraiture, but rather in terms of self-presentation. ${ }^{20}$

A famous Venetian precedent for Guercino's choice to depict the musician as a clear reference to a painter may be seen in Paolo Veronese's Wedding at Cana (Figure 11), originally for the refectory of the San Giorgio Maggiore Monastery in Venice, and now at the Louvre.

Veronese, depicted himself together with fellow painters Titian, Tintoretto, and Bassano, as musicians at the centre of the composition. ${ }^{21}$ Guercino must have seen the painting during his visit to Venice, in its original location (the painting was looted by the French during Napoleon Bonaparte's invasion) (Fehl 1981, p. 341; Riley 2007, pp. 570-71). Both Malvasia and Passeri report that in 1618, the year in which Guercino painted the Return of the Prodigal Son, he visited Venice and met the most important painter working there at the time-Titian's student Jacopo Negretti (known as Palma il Giovane), who showed him around the city (Malvasia 1678, vol. 2, p. 259; Passeri 1772, p. 373). Since Veronese's painting was very famous and was located at the heart of Venice, it would seem implausible for Guercino not to have seen it. 


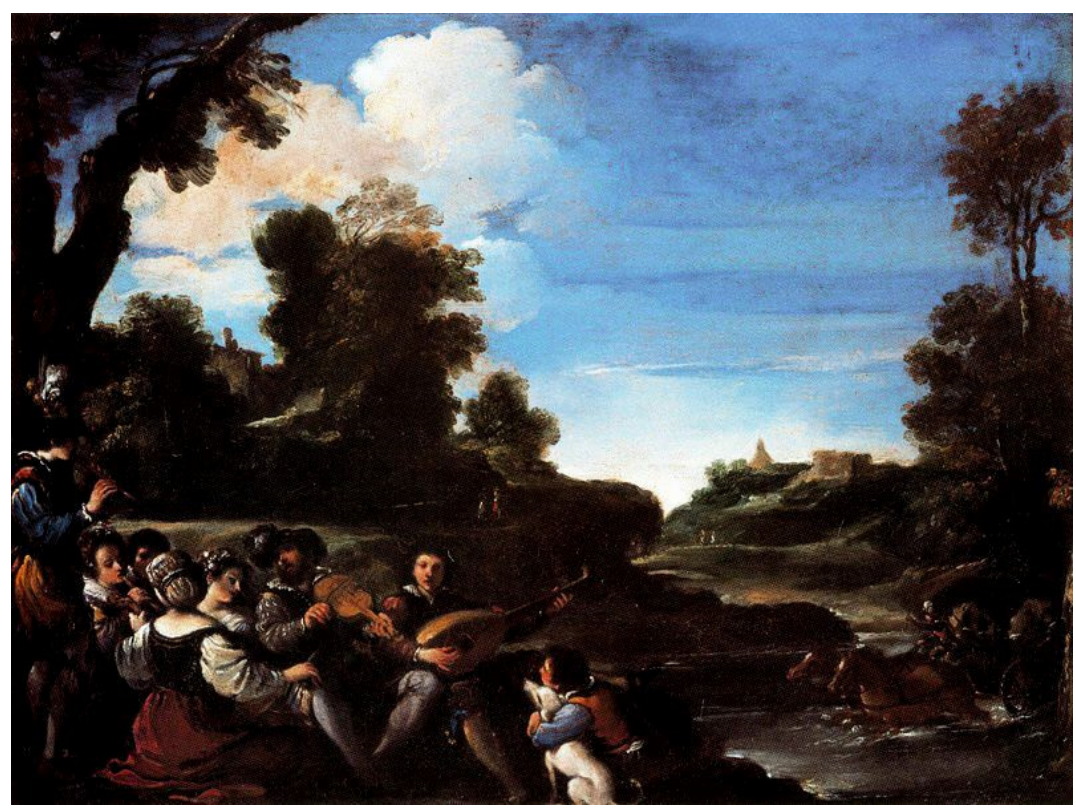

Figure 10. Guercino, Landscape with a Concert, 1617, Uffizi, Florence. Photo: Wikimedia Commons, Public Domain.

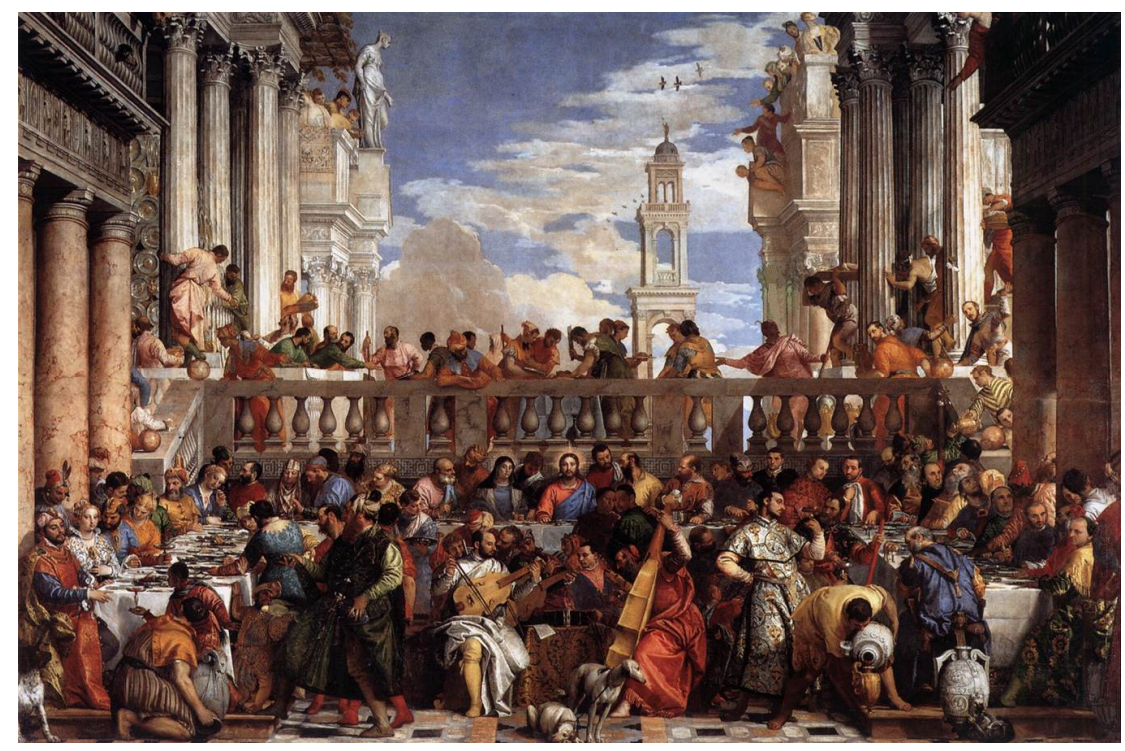

Figure 11. Paolo Veronese, Wedding at Cana, 1562/3, Louvre, Paris. Photo: Wikimedia Commons, Public Domain.

Indeed, there are several similarities between Veronese's painting and Guercino's Return of the Prodigal Son. The first is the use of an architectural setting comprised of a series of buildings, which form a street depicted in foreshortening. Whereas Veronese positioned three Palladian palaces, one after the other, on either side of the painting to construct the allusion of a street, Guercino achieved a similar effect with two palaces at the centre of the painting. The two buildings represent two different architectural styles, one more elaborate than the other. In Veronese's painting, a man in fancy dress stands on the right side, appreciating a glass of wine. This figure, too, is echoed by Guercino, who depicted an arriving spectator about to enter the staircase on the right.

According to Philipp Fehl (1981, p. 348), Veronese's depiction of his fellow painters as musicians was meant to stress the similarity between the role of the painter and that of a musician, who is supposed to support the believer in his spiritual exercise. The painting, 
like the sound of music, was meant to inspire apprehension of a moment of sacred truth. This idea is similarly emphasized in Guercino's painting by the scene of the prodigal son's return, which has paramount significance for Catholics in relation to the sacrament of penitence. This allusion to the sacrament underscores Guercino's vocation as a religious painter.

\section{A Self-Presentation}

Guercino was not in the habit of producing self-portraits, and the few rare exceptions that are attributed to him indicate that the image of the musician in Return of the Prodigal Son is not a self-portrait and his presence is meant to accentuate a different type of endeavour. ${ }^{22}$ There are several known self-portraits of Guercino in different mediums and techniques (Turner 2017, pp. 21-30), including the two self-portraits done in oil on canvas mentioned here. In one of them (Figure 12), the painter depicted himself from the chest up, with his left hand holding his palette and brushes. The other hand is not visible in the painting. In the late version (Figure 13), painted when Guercino was over sixty years old, he depicted himself from the waist up before a painting of "Amor Fedele", holding a palette and a few brushes in his left hand and another brush in his right hand. This painting, which was completed many years after the first version, is much more sophisticated. As pointed out by Prasad (2006, p. 34), in this case Guercino emphasizes his squint through a witty game of two points of view (as if each seen through one eye). In addition, he presents himself as both the author and the subject (Prasad 2007, p. 6). Still, there are a few similarities between these two self-portraits that deserve our attention. Firstly, in both paintings the painter is similarly positioned, with his shoulder rotated toward the viewer and his head turned slightly to the left, as if gazing at the viewer (at least with one eye). In both paintings, he is portrayed with long hair, wearing the same black clothes and sporting a large white collar. The squint visible in both paintings is also apparent in Ottavio Leoni's rendition of the painter from 1623 (Figure 14).

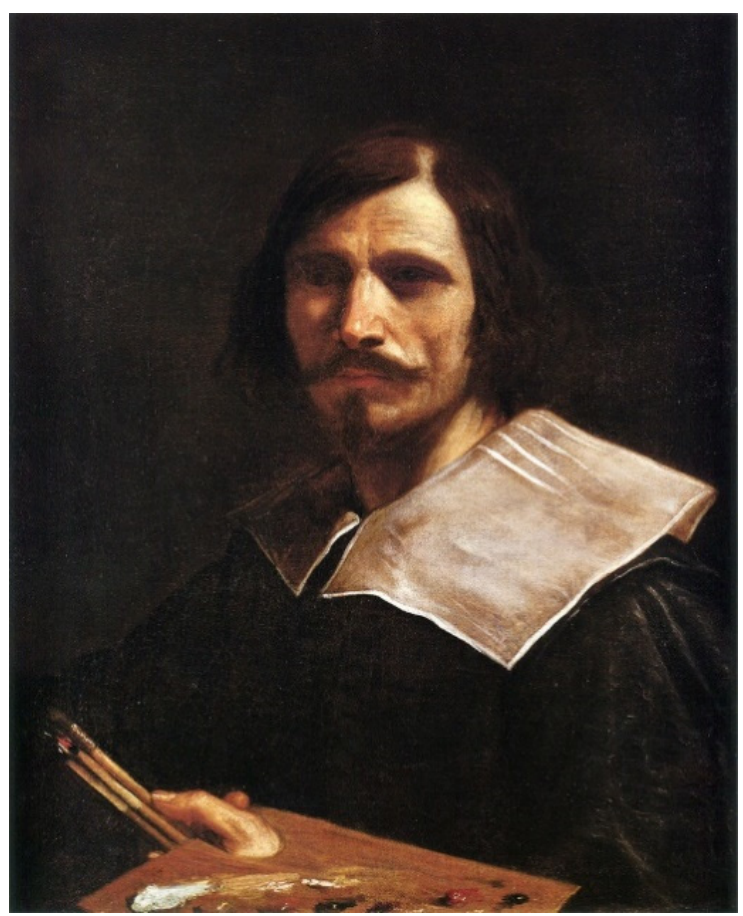

Figure 12. Guercino, Self-Portrait, 1635/40, London, Schoeppler Collection. Photo: Wikiart, Public Domain. 


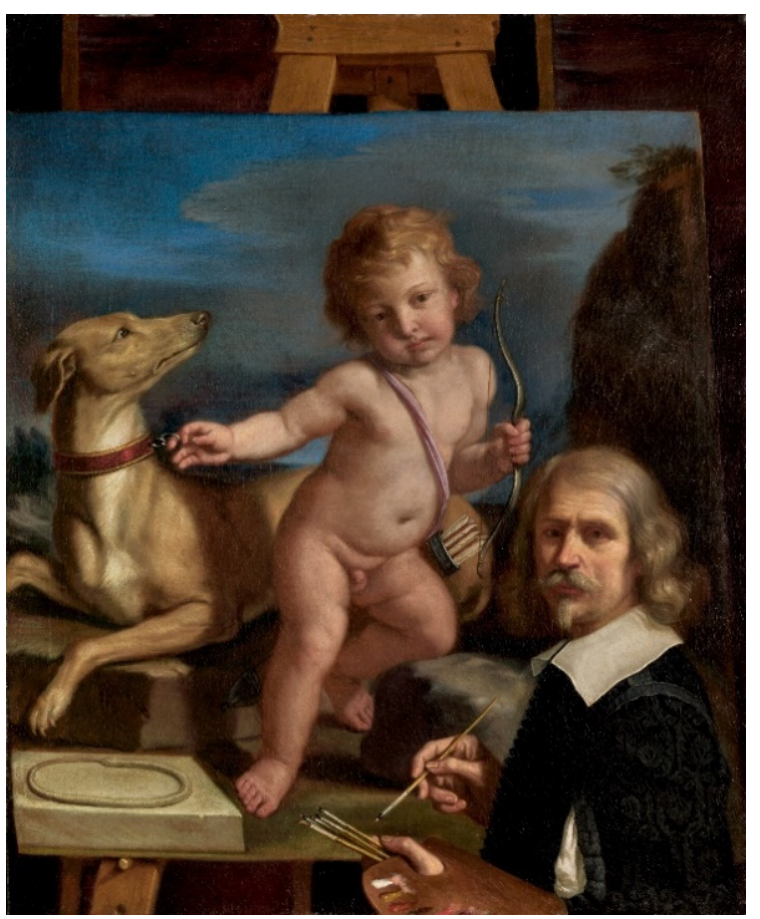

Figure 13. Guercino, Self-Portrait before a Painting of "Amor Fedele", 1654/5, National Gallery, Washington DC. Digital image courtesy of the National Gallery of Art, Washington Open Access Program.

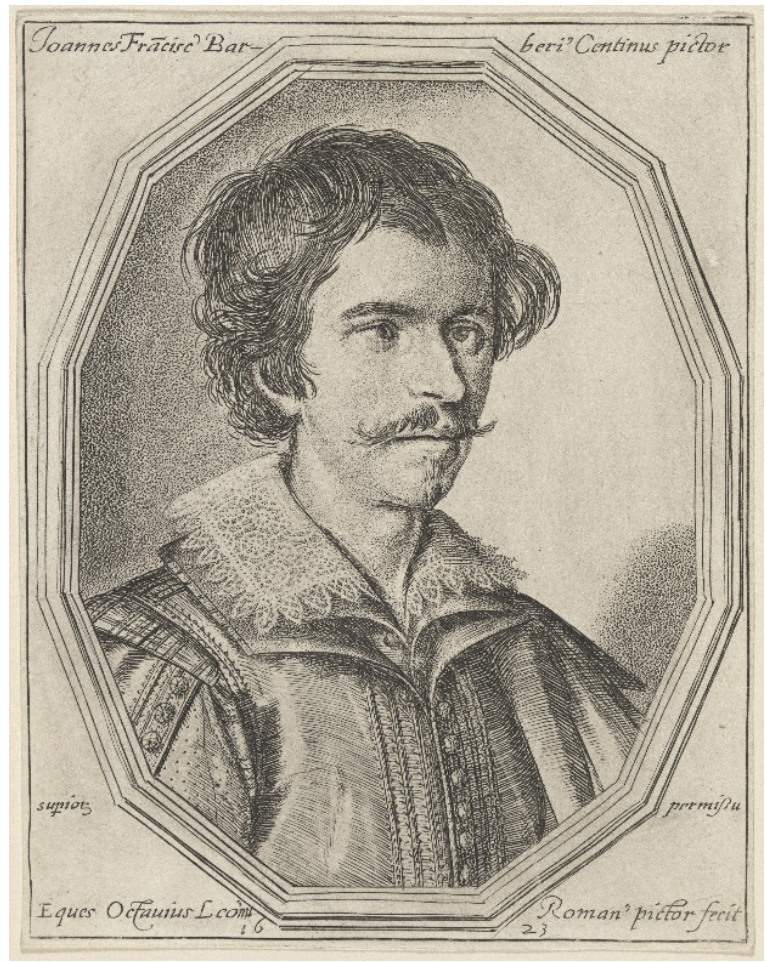

Figure 14. Ottavio Leoni, Portrait of Guercino (engraving), 1623, Royal Collection Trust, London. Photo: Wikimedia Commons, Public Domain.

A comparison between these two self-portraits and the figure of the musician in the Return of the Prodigal Son reveals a resemblance between the musician's handling of the lira da braccio and the painter's handling of the palette and brushes. What is emphasized in all three paintings is the way both the painter and the violinist hold their instruments with the thumb prominently displayed. Additionally, Return of the Prodigal Son can be seen as a 
precedent for Self-Portrait before a Painting of "Amor Fedele", in that it contains an additional scene which emphasizes the painter as both the author and the subject. At the same time there are obvious differences between the rendition of the musician and the self-portraits, most notable of which is the portrayal of the painter with his trademark squint. The musician, by contrast, has no notable facial features, and does not resemble Guercino. It is thus easy to ascertain that the figure of the musician is not a self-portrait, although he does seem to be a symbolic representation of a painter. In his An Anthropology of Images, Hans Belting (2011, pp. 62-67) distinguishes between two types of early modern representations of a subject: a 'body image', which is an attempt to persuasively portray a living person, and a 'body sign', which marks and identifies a given subject by means of a heraldic, abstracted notion such as a coat-of-arms. Whereas the first form of identifying an individual relies on physiognomic duplication, the other is a genealogical emblem that is recognized with the help of identifiable marks. Using Belting's definitions, one may regard Guercino's violinist as a symbolic image of the painter-what he calls a heraldic face (Belting 2011, p. 72). He is there to capture the beholder's gaze, hinting at an interpretation that is a diversion both from the return of the prodigal son and from its theatrical performance. Indeed, the violinist points towards a new meaning, one that involves the interrelationship between a painter and his patron.

As a self-presentation of a painter whose gaze is directed toward the viewer-Cardinal Ludovisi-the violinist/painter becomes a crucial sign for understanding the painting's political dimension, marking an additional lens through which the beholder may view the scene. Thus, the straightforward meaning of the prodigal son's contrition, portrayed in the most conventional way, is enhanced by a theatrical frame, marked by adding musicians and spectators to the composition. Within these groups of secondary figures, one may discern the violinist/painter as a signifier that calls for an additional reading of the painting.

\section{Music}

In forging a connection between painting and music, Guercino was relying on the affinity noted between these two mediums in both sixteenth-century treatises and works of art (Veronese). The main emphasis in both verbal and visual forms was on a comparison between the harmony of colours and the harmony of sounds (Lever 2019, pp. 72-77, 22630). Leonardo, who was himself a musician, and even a music teacher (Winternitz 1982), emphasized the importance of finding the precise relationships between different parts for the sake of creating a perfect harmony of rhythms. Yet although he regarded painting and music as sister arts because they were both characterized by the simultaneity of their elements, he considered music as inferior to painting, because the sense of hearing was inferior to the sense of sight (Winternitz 1970, p. 280; Farago 1999, pp. 99-100). For Giovanni Paolo Lomazzo, art "is largely composed of this science [architecture] along with music, which, too, is so essential that, lacking it, the painter would be imperfect" (Lomazzo 2013, p. 71). ${ }^{23}$ For Lomazzo, harmony is the component that is necessary for art to be pleasurable: "indeed, each artist applied all his care and efforts to fully understanding this harmonious beauty, especially Leonardo, Michelangelo, and Gaudenzio. They acquired knowledge of harmonious proportions through music and through insight into the structure of our body, itself fabricated according to musical consonances" (Lomazzo 2013, p. 145). Pietro Testa compared colours to musical notes, arguing that the rules of musical harmony are comparable to the rules of colour, and that musical scale is analogous to the tonality of colour (Cropper 1984, pp. 138, 223). Marco Boschini, who marvelled in his La carta del navegar pitoresco about the artistic abilities of Venetian painters, used musical terms to express his amazement. He writes (Boschini 1660, p. 294) that the Venetian painters are expert musicians who masterfully control their instruments, noting that their virtuosic use of colour may be compared to a musical concert in which the strings of a musical instrument become loose, yet the music remains graceful. This hyperbolic description emphasizes the painters' extraordinary abilities. In this context, it is also noteworthy that Malvasia began his biography of Guercino by comparing colour with voice, associating the 
painter's greatness with his skill as a colourist and comparing this ability to a singer whose most important trait is a beautiful voice (Malvasia 1678, vol. 2, p. 359; Prasad 2007, pp. 29, 116-20). This analogy, common in early modern treatises, might suggest the biographer's awareness of Guercino's own self-perception in terms taken from the world of music.

\section{The Act of Viewing}

My explanation for Guercino's choice of depicting the return of the prodigal son in a theatrical environment, with the violinist on the balcony representing the artist, is that it was intended as a message directed at the work's aimed applicant. The derivation of the word 'theatre' from the Greek theaomai, which means 'look', casts it as a metaphor of knowing or learning through seeing (West 2002, pp. 45-47). Looking or seeing, as Giovanni Andrea Gesualdo writes in his 1541 commentary on Petrarch's Trionfi, is the most important among the five senses: "And even though one learns through all the senses, nonetheless it is the sense of sight that provides information about the most beautiful and varied things". ${ }^{24}$ In his 1657 treatise on theatre, commissioned by Cardinal de Richelieu, the French playwright François Hédelin, Abbé d'Aubignac (Hédelin 1657, p. 6), regarded theatre as "the people's school", noting that it was the only way to teach morality to the lower ranks. In his book Theatres and Encyclopedias in Early Modern Europe, William N. West (2002, pp. 1-11) underscores the interpretive role of early modern theatrical culture in regard to knowledge, truth, and authority. What he calls a 'performance of knowledge', is, in effect, a pedagogical institution in which a princely patron controls the meaning of things. The theatre served as a way to convey messages, teach, transmit knowledge and provide explanations. In effect, the theatre was able to "represent and transmit the universal knowledge of everything" (West 2002, p. 114; Bouwsma 2000, pp. 129-42, especially, pp. 132-34). As Ornat Lev-er writes in Still-Life as Portrait in Early Modern Italy, humanists and scholars added to the titles of their theoretical and philosophical treatises the Latin word for theatre, teatrum, as a metaphor for reason, critical thinking, and observation (Lever 2019, p. 181). The use of a theatrical performance may have been chosen to present Cardinal Ludovisi with Guercino's true vocation-that of representing his patrons' ideas, thoughts or interpretations by means of his critical power to deliver sophisticated messages through artistic wit and creativity. This aim may explain why the painting does not depict the prodigal son returning home, but rather emphasizes a theatrical problem: although the narrative's climax - the joyful father's embrace of his long-lost son-is underscored, the musicians are not playing their instruments, and one of them is looking at the viewer. The man on the right, who represents the audience, has just arrived. Guercino was challenging his viewer by making a claim to his ability to deliver a message. Standing on a theatre balcony, his violinist/painter acts as an admonisher, through whom Guercino is advertising himself as a painter who has the ability to direct attentive viewers towards the artwork's message. The choice of a theatrical setting, in this context, further enhances the importance of sight, which the painter makes use of in order to communicate with his viewers. The portrayal of a religious theme against a theatrical backdrop thus serves to allude to the sacrament of penitence, alongside an additional message-one concerning the painter's employment of his skills in the service of his patron.

\section{Conclusions}

Guercino's Return of the Prodigal Son is a unique painting in that a more sophisticated level of meaning is added to the story's traditional understanding. This added value relates to the relationship between the painter and his patron, and the private message delivered by the former to the latter. Guercino communicates a personal note-his ability to convey ideas, thoughts or interpretations by means of his critical power to deliver sophisticated messages through artistic wit and creativity.

What is exceptional about the painting is the portrayal of a violinist who directs his gaze at the viewer, and his handling of the lira da braccio in a manner that casts him as a representative of the painter. This is not a self-portrait. Rather than a self-portrait, 
this figure was meant to be identified as a symbol, sign, or signature of the painter. The contrast between the main scene in the story of the prodigal son's return and the theatrical setting suggests that it was meant to be identified by the intended recipient of the paintingCardinal Alessandro Ludovisi-as a conceit that relates to the agent-painter and his abilities to organize a composition.

One may assume that Cardinal Alessandro Ludovisi understood Guercino's intentions. This can be deduced by the subsequent invitation of Guercino to Rome, where he received from the Ludovisi pope his most important commission-the Petronilla altarpiece for St. Peter's.

Guercino's Return of the Prodigal Son may be comprehended as belonging to the group of paintings that were produced for the sake of promoting a career. Embracing a setting of a theatre, adding to the main protagonists of a religious scene groups of secondary figures that belong to the theatre were meant to divert the attention of a traditional iconography and thus a traditional message towards something else. Adding musicians and viewers to a composition that is meant to show the return of the prodigal son, may be seen as a marketing choice. The most noticeable aspect of this work is Guercino's ability to shift the attention of a given iconography and deliver current political meaning by instilling crucial elements that shift the viewer's attention and add another layer of meaning to the painting.

Funding: This research received no external funding.

Conflicts of Interest: The authors declare no conflict of interest.

\section{Notes}

1 Alessandro Ludovisi received the red hat in 20 November 1618. He was elected pope on 9 February 1621, and chose to be called by the name of another Bolognese pope, Gregory XIII (Boncompagni). See (di Paolo Masini 1666; von Pastor 1891/1953, pp. 45-46).

2 For the special connection between the artist and Pope Gregory XV, see (Mahon 1981, p. 230).

3 A letter by Ludovico Carracci, dated 19 July 1617, to Don Ferrante Carlo, secretary to Cardinal Scipione Borghese, mentions Guercino as working for the archbishop in Bologna: “ . . è pur giunto un messer Giovan Francesco da Cento, ed è qua per fare certi quadri al Signor cardinal arcivescovo, e si porta eroicamente" (Perini 1990, p. 140).

4 Although Alessandro Ludovisi received his appointment in Bologna as early as 12 March 1612, he did not arrive in the city until 1619. In 1616, however, his nephew Ludovico Ludovisi, was already an archpriest in Bologna, and very likely it was he who ordered the three paintings on behalf of his uncle. Ludovico Ludovisi later joined his uncle in the latter's diplomatic missions on behalf of Pope Paul V in Turin and Milan. On Alessandro's appointment to Bologna, see (Faleoni 1649, p. 654; von Pastor 1891/1953, p. 45).

$5 \quad$ Ludovico Ludovisi's collection was housed at the Casino Ludovisi, which he purchased from Cardinal del Monte, on 3 June 1621. Guercino completed two major ceiling decorations in the Casino for the Ludovisis-Triumph of Aurora and Allegory of Fame. On Ludovico's private collection, see (von Pastor 1891/1953, pp. 60-62; Garas 1967a, pp. 287-90; Garas 1967b; Wood 1992). On the purchase of the palace, see (Felici 1952, p. 132; Wood 1986, pp. 223-24).

6 “Fù chiamato dall'Eminentissimo Sig. Cardinale Ludovisio all hora Arcivescovo di Bologna, che fù poi Gregorio XV. e per lui fece diversi quadrì cioè: Un miracolo di S. Pietro, che resuscita una fanciulla, che fù poi intagliato benissimo dal Bloemart. Una Susanna, ricavata da bella Donna entro a quelle carceri Arcivescovali. Un figliol prodigo, che surono opre maggiori dell'aspettatione del medemo Sig. Cardinale". (Malvasia 1678, vol. 2, p. 363). See also, (Mahon 1968, p. 54; Salerno 1988, p. 114). Another letter written by Don Antonio Mirandola to Enzo Bentivoglio, dated 7 December 1617, mentions Guercino as a busy painter who is currently working for Cardinal Ludovisi: "Ho fatto quanto ho potuto, acciò M. Gio. Francesco, fra tanti oblighi di lavori, che ha e con il Gran Duca, e l'Ill. mo Cardinale Ludovisi ... ". See, (Bagni 1984, p. 269, doc. 3; Turner 2017, p. 7, n. 15). For Alessandro Ludovisi as a collector of Guercino's paintings, see (Morselli 2019, pp. 47-49).

$7 \quad$ For the mention of Susanna and the Elders, see (Wood 1992, p. 518; Garas 1967b, p. 339).

8 See, (Turner 2017, p. 301). For the 1631 inventory, see (Campori 1870, p. 76).

9 For the type of musical instruments depicted in Guercino's drawing, see, (Praetorii 1620, vol. 2, p. i, p. xvi and p. xx).

10 For a discussion of this drawing, see (Prasad 2007, pp. 12-18).

11 For the letter, see (Bagni 1984, pp. 14-15, 268-70). See also (Malvasia 1678, vol. 2, p. 258; Prasad 2006, p. 10; Bagni 1984, pp. 6-7; Salerno 1988, p. 8). Frances Gage published a letter, written in 22 January 1624 by Giovanni Battista Bandi, and sent to Deifebo Mancini, which indicates Guercino's involvement in constructing a stage decoration for the play Pastor Fido in 1624. See (Gage 2014, pp. 653-56). 
This point has been made by Shilpa Prasad (2007, p. 53).

For Castelvetro's influence on Guercino, see (Turner 2017, pp. 174-78).

14 Aristotle, Poetics, chap. 8: “ ... so in poetry the story, as an imitation of action, must represent one action, a complete whole, with its several incidents so closely connected that the transposal or withdrawal of any one of them will disjoin and dislocate the whole". (Mckeon 1941, p. 1463). For the addition of the unity of time and the unity of place to the notion of the unity of action, see (Castelvetro 1570, p. 60 verso). See (Travis 1982, pp. 39-40).

“La Pitura xè come una Comedia: I Spetatori stà in Teatro, e in sedia, E osserva i Recitanti”. (Boschini 1660, p. 14). It is interesting to note that the parable of the prodigal son was viewed as a comedy by the German preacher Georg Witzel. See (Delcorno 2018, p. 416).

16 For the history of parable of the prodigal son as a religious drama, see (Delcorno 2018).

17 On the Borghese version, see (Mahon 1968, p. 151; Salerno 1988, cat. no. 120; Stone 1991, cat. no. 110).

18 In addition to the many known depiction of musical instruments, one should mention that in $1615 / 17$, Guercino decorated the Casa Pannini in Cento. In the room dedicated to music, Guercino painted musical instruments accompanied by a text. The entire decoration is lost today. See (Atti 1861, p. 27; Bagni 1984, p. 163). See also, (Plank 2013, p. 448). See Plank's reading of the painting in (Plank 2013, especially pp. 450-54). For the notion of self-presentation, see (Crozier and Greenhalgh 1988, p. 29). For the musicians as representatives of the four Venetian painters, see (Hanson 2010, p. 47).

For the early self-portrait, see (Loire 1989, pp. 266-67; Mahon 1991, cat. no. 62; Prasad 2007, pp. 211-12; Turner 2017, pp. 21-29). On Lomazzo's connection between painting and music, see (Korrick 2003, pp. 193-214).

(Gesualdo 1541, ch. 1, n.p). The translation of this sentence is taken from (Cropper 1984, p. 66).

\section{References}

Atti, Gaetano. 1861. Intorno Alla Vita e Alla Opera di Gianfrancesco Barbieri Detto il Guercino di Cento. Rome: Tipografia delle scienze matematice e fisiche.

Bagni, Prisco. 1984. Guercino a Cento: Le decorazioni di Casa Pannini. Bologna: Nuova Alfa Editoriale.

Belting, Hans. 2011. An Anthropology of Images: Picture, Medium, Body. Princeton and Oxford: Princeton University Press.

Boschini, Marco. 1660. La Carta del Navegar Pitoresco: Dialogo tra un Senator Venetian Deletante, e un Professorde Pitura Soto Nome d'Ecelenza, e de Compare. Venice: li Baba.

Bouwsma, William J. 2000. The Waning of the Renaissance 1550-1640. New Haven: Yale University Press.

Campori, Giuseppe. 1870. Raccolta di Cataloghi ed Inventari Inediti di Quadri, Statue, Disegni, Bronzi, Dorerie, Smalti, Medagli, Avorii, Ecc. Dal Secolo XV al secolo XIX. Modena: Carlo Vincenzi.

Carr, Carolyn Kinder. 1978. Aspects of the Iconography of Saint Peter in Medieval Art of Western Europe to the Early Thirteenth Century. Ph.D. thesis, Case Western Reserve University, Cleveland, OH, USA.

Castelvetro, Lodovico. 1570. Poetica d'Aristotele Vulgarizzata, et sposta. Vienna: Gaspar Stainhofer.

Cropper, Elizabeth. 1984. Ideal of Painting: Pietro Testa's Düsseldorf Notebook. Princeton: Princeton University Press.

Crozier, W. Ray, and Paul Greenhalgh. 1988. Self-Portraits as Presentations of Self. Leonardo 21: 29-33. [CrossRef]

Delcorno, Pietro. 2018. In the Mirror of the Prodigal Son: The Pastoral Uses of a Biblical Narrative (c. 1200-1550). Leiden: Brill.

di Paolo Masini, Antonio. 1666. Bologna Perlustrata: Terza Impressione Notabilmente Accresciuta in Cui Si Fa Mentione Ogni Giorno in Perpetuo Delle Fontioni Sacre, e Profane di Tutti L'anno. Bologna: Vittorio Benacci.

Faleoni, Celso. 1649. Memorie Histoirche Della Chiesa Bolognese e Suoi Pastori. Bologna: G. Monti.

Farago, Claire, ed. 1999. Leonardo's Writings and Theory of Art. New York: Garland.

Fehl, Philipp P. 1981. Veronese's Decorum: Notes on the Marriage at Cana. In Art the Ape of Nature: Studies in Honor of H. W. Janson. Edited by Moshe Barasch and Lucy Freeman Sandler. New York: Harry N. Abrams, Englewood Cliffs: Prentice-Hall, pp. 341-65.

Felici, Giuseppe. 1952. Villa Ludovisi in Roma. Rome: Sansaini.

Forsook, Eve, and Johannes Offerhaus. 1981. Francesco Sassetti and Ghirlandaio at Santa Trinita, Florence: History and Legend in a Renaissance Chapel. Doornspijk: Davaco.

Gage, Frances. 2014. New Documents on Giulio Mancini and Guercino. Burlington Magazine 156: 653-56.

Garas, Klara. 1967a. The Ludovisi Collection of Pictures in 1633-I. Burlington Magazine 109: 287-91.

Garas, Klara. 1967b. The Ludovisi Collection of Pictures in 1633-II. Burlington Magazine 109: 339-48.

Gesualdo, Giovanni Andrea. 1541. Il Petrarcha Colla Spositione di Misser Giovanni Andrea Gesualdo. Venice: Giovann' Antonio di Nicolini \& fratelli da Sabbio.

Ghelfi, Barbara, ed. 1997. Il libro dei conti del Guercino 1629-1666. Bologna: Nuova Alfa.

Hanson, Kate H. 2010. The Language of the Banquet: Reconsidering Paolo Veronese's Wedding at Cana. Invisible Culture 14. Available online: https:/ /ivc.lib.rochester.edu/the-language-of-the-banquet-reconsidering-paolo-veroneses-wedding-at-cana/ (accessed on 18 July 2021). 
Hédelin, François. 1657. La Pratique du Théâtre: Ouvre Tres-Necessaire a Tous Ceux Qui Veulent S'appliquer à la Composition des Poëmes Dramatiques, Qui Font Profession de les Reciter un Public, ou Qui Prennent Plaisir d'en voir Les Representtions. Paris: Antoine de Sommaville.

Hornik, Heidi J., and Mikeal C. Parsons. 2005. Illuminating Luke: The Public Ministry of Christ in Italian Renaissance and Baroque Painting. New York: T\&T Clark.

Huddleston, Robert S. 2001. Baroque Space and the Art of the infinite. In The Theatrical Baroque. Edited by Larry F. Norman. Chicago: The David and Alfred Smart Museum of Art and The University of Chicago.

Korrick, Leslie. 2003. Lomazzo's Trattato ... della pittura and Galilei's Fronimo: Picturing Music and Sounding Images in 1584. In Art and Music in the Early Modern Period: Essays in Honor of Franca Trinchieri Camiz. Edited by Katherine A. McIver. London: Routledge, pp. 193-214.

Lever, Ornat. 2019. Still-Life as Portrait in Early Modern Italy: Baschenis, Bettera, and the Painting of Cultural Identity. Amsterdam: Amsterdam University Press.

Lightbown, Ronald. 1978. Sandro Botticelli. Berkeley: University of California Press, 2 vols.

Loire, Stéphane. 1989. Etudes recéntes sur Le Guerchin. Storia dell'arte 67: 263-77.

Lomazzo, Giovan Paolo. 2013. Idea of the Temple of Painting. Edited by Jean Julia Chai. University Park: The Pennsylvania University Press.

Mahon, Denis. 1968. Il Guercino (Giovanni Francesco Barbieri, 1591-1666) Catalogo Critico dei Dipinti. Bologn: Nuova Alfa.

Mahon, Denis. 1981. Guercino as a Portraitist and his Pope Gregory XV. Apollo 113: 230-35.

Mahon, Denis, ed. 1991. Giovanni Francesco Barbieri: Il Guercino 1591-1666. exh. cat. Bologna: Nuova Alfa Editoriale.

Malvasia, Carlo Cesare. 1678. Felsina Pittrice: Vite de' Pittori Bolognesi. Bologna: Domenicho Barbieri, 2 vols.

Mckeon, Richard, ed. 1941. The Basic Works of Aristotle. New York: Random House.

Morselli, Raffaella. 2019. Il desiderio di tutti: Guercino tra i suoi collezionisti, agenti, intermediary e banchieri. In Il Guercino: Opere da quadrerie e collezioni da Seicento. Edited by Elena Rossoni and Luisa Berretti. Aosta: Forti di Bard, pp. 47-57.

Paolucci, Antonio. 2003. Botticelli and the Medici: A Privileged Relationship. In Botticelli: From Lorenzo the Magnificent to Savonarola. Milan: Skirl Editor, pp. 69-76.

Passeri, Giovanni Battista. 1772. Vite de' Pittori, Scultori ed Architetti: Che Anno Lavorato in Roma Morte dal 1641 Fino al 1673. Rome: Presso Gregorio Settari.

Perini, Giovanna, ed. 1990. Gli Scritti dei Carracci: Ludovico, Annibale, Agostino, Antonio, Giovanni Antonio. Bologna: Nuova Alfa.

Pinelli, Antonio, ed. 2000. The Basilica of St. Peter in the Vatican. Modena: Franco Cosimo Panini.

Plank, Steven E. 2013. [Uno] Miracolo da far stupire: Transformation and Il Guercino's St. Francis in Ecstasy with St. Benedict. Franciscan Studies 71: 445-61. [CrossRef]

Praetorii, Michaëlis. 1620. Theatrum Instrumentorum: Seu Sciagraphia. Wolffenbüttel: S. N, 2 vols.

Prasad, Shilpa. 2006. Guercino: Stylistic Evolution in Focus. exh. cat. San Diego: Timken Museum of Art.

Prasad, Shilpa. 2007. Modes of Representation: Genre, Theater, Music and Voice in the Work of Guercino. Ph.D. thesis, Johns Hopkins University, Baltimore, MD, USA.

Rice, Louise. 1997. The Altars and Altarpieces of New St Peter's: Outfitting the Basilica 1621-1666. Cambridge: Cambridge University Press. Riley, Gillian. 2007. The Oxford Companion to Italian Food. Oxford: Oxford University Press.

Salerno, Luigi. 1988. I dipinti del Guercino. Rome: Ugo Bozzi.

Steinberg, Leo. 1980. Guercino's Saint Petronilla. In Studies in Italian Art and Architecture 15th through 18th Centuries. Edited by Henry A. Millon. Cambridge: MIT Press, pp. 207-42.

Stone, David M. 1991. Guercino: Catalogo Completo dei Dipinti. Florence: Cantini.

Travis, Priscilla Jane Masavage. 1982. The Three Unities: Their History and Application in the Development of Dramatic Criticism and Technique in England and France before 1800. Ph.D. thesis, The University of Michigan, Ann Arbor, MI, USA.

Turner, Nicholas. 2017. The Paintings of Guercino: A Revised and Expanded Catalogue raisonné. Rome: Ugo Bozzi Editore.

Unger, Daniel M. 2010. Guercino's Paintings and His Patrons' Politics in Early Modern Italy. Farnham: Ashgate.

Unger, Daniel M. 2012. The Pope, the Painter, and the Dynamics of Social Standing in the Stanza della Segnatura. Renaissance Studies 26: 269-87. [CrossRef]

Vivian, Frances. 1971. Guercino seen from the Archivio Barberini. Burlington Magazine 113: 22-29.

von Pastor, Ludwig. 1891/1953. The History of the Popes from the Close of the Middle Ages. Translated and Edited by Dem Ernest Graf. London: J. Hodges, vol. 27.

West, William N. 2002. Theatres and Encyclopedias in Early Modern Europe. Cambridge: Cambridge University Press.

Winternitz, Emanuel. 1970. The Role of Music in Leonardo's Paragone. In Phenomenology and Social Reality: Essays in Memory of Alfred Schutz. Edited by Maurice Natanson. The Hague: Martinus Nijhoff, pp. 270-96.

Winternitz, Emanuel. 1982. Leonardo da Vinci as a Musician. New Haven: Yale University Press.

Wood, Carolyn H. 1986. Visual Panegyric in Guercino's Casino Ludovisi Frescoes. Storia dell'arte 58: 223-28.

Wood, Carolyn H. 1988. The Indian Summer of Bolognese Painting: Gregory XV (1621-1623) and Ludovisi Art Patronage in Rome. Ph.D. thesis, University of North Carolina, Chapel Hill, NC, USA.

Wood, Carolyn H. 1992. The Ludovisi Collection of Painting in 1623. Burlington Magazine 134: 515-23. 